\title{
The Integration of Character Values in the Teaching of Economics: A Case of Selected High Schools in Banjarmasin
}

\author{
Rizali Hadi ${ }^{1}$ \\ ${ }^{1}$ Faculty of Education, Universitas Lambung Mangkurat, Indonesia \\ Correspondence: Rizali Hadi, Faculty of Education, Universitas Lambung Mangkurat, Jl. Brigjen H. Hasan Basri, \\ P. O. Box 219, Banjarmasin 70123, South Kalimantan, Indonesia. E-mail: rizalihadi15@gmail.com
}

Received: October 22, 2014 Accepted: January 19, 2015 Online Published: June 10, 2015

doi:10.5539/ies.v8n7p11

URL: http://dx.doi.org/10.5539/ies.v8n7p11

\begin{abstract}
Character education is currently an international issue and schools are deeply involved in its dissemination. In Indonesia, teachers have been introduced to various methods and techniques of how to integrate character values with subject-matter content during teaching-learning processes. Since teaching character values together with subject matter content is a new aspect for the Indonesian schools, there is limited research on how Indonesian schools have performed in this line. Thus, the present study aimed to discover how teachers integrate character values with other subject matter during classroom sessions (i.e., during teaching and learning). The respondents were economics teachers from a few selected high schools in Banjarmasin. A qualitative method was used for data collection and analysis, while interviews and classroom observations were used as major techniques for the data collection. The findings revealed that teachers were capable of identifying character values appropriate for integration with subject matter; however, the studied respondents appeared to be limited in skills, and were hesitant in applying the correct methods during the teaching-learning processes. Following such findings, it is recommended that this study is used as a reference in the teaching of character values, mostly by economics teachers in schools across Indonesia. This is fundamental because character education is essential to the current Indonesian education system. To integrate character values while teaching subject matter content is one of the roles a teacher should perform in building quality and trusted human resource.
\end{abstract}

Keywords: Banjarmasin, character education, economics, high school, learning model

\section{Introduction}

Character education practitioners are currently searching for a model for teaching character values to students. Previously, character education was considered the responsibility of teachers of religion or civic education, and guidance and counseling teachers. However, following the 2013 curriculum, teachers are required to integrate character education into their teaching-learning processes. In this case, a model that promotes the integration of good values into classroom sessions is needed. Teachers are required to play the role of integrating good values suitable for their specific subjects into their teaching. Identifying an appropriate model for teaching good character fits with the aims of national education as pointed out in Indonesia's Constitution No. 20 of 2003 (Departemen Pendidikan Nasional, 2003) which, among other things, emphasizes the importance of teaching core values that are deeply rooted in religious and national culture, and the need to respond to current educational demands.

Teachers have participated in several training programs on how to make lesson plans that can contribute to character building (Kementerian Pendidikan Nasional, Badan Penilitian dan Pengembangan Kurikulum, 2010). Nevertheless, this study found that teachers actually incorporated the teaching of values into their lesson plans by choosing some values suggested by Indonesia' Ministry of Education and culture, however, some teachers are still hesitant in integrating such values into their actual teaching practices (Depdiknas, 2007). This research led to a model meant to impart greater confidence in teachers including in the teaching of character values to students.

Therefore, this study was undertaken in response to the integration of character education into other subjects in accordance with the 2013 curriculum in Indonesia (Kementerian Pendidikan Dan Kebudayaan, 2012). Teachers experience doubts because of the inclusion of the variable "character" into their lesson plans. There are no standard guidelines on how to teach character through subject matter (Fadillah, 2010), i.e. the way to incorporate 
character values into the teaching-learning processes. This study sought to establish how public high school teachers in the city of Banjarmasin, Indonesia conduct the learning of values or character through the teaching of economics with values or character integrated into the subject.

\section{Theoretical Foundation}

The most frequently offered solution to overcome or at least reduce the magnitude of the problem of character deviation in society is through education. One's character should generally be maintained in a way to preserve good characteristics and maintain the unique aspects of each individual.

Etymologically, the word "character" has its root in Latin, namely kharakter, kharassein, and kharax, which mean "tool for marking," "to engrave," and "to point to stoke," respectively. In French, it is caractere and in English "character," both of which express similar concepts (El-Mubaroq, 2008).

Character education may be defined as a type of education that aims to nurture a child's behavior and personality through moral and ethical education. The purpose of this kind of education is to cultivate the values of honesty, responsibility, respect for others, and hard work (Poerwanti, 2011). Lickona (1992) in a translation by Wamaungo (2012) says that character education should involve moral knowing, moral feeling, and moral action. To arrive at the moral action dimension, an elaborate process is required and education has to play an active role. The interconnectedness among moral knowing, moral feeling, and moral action is shown in Figure 1.

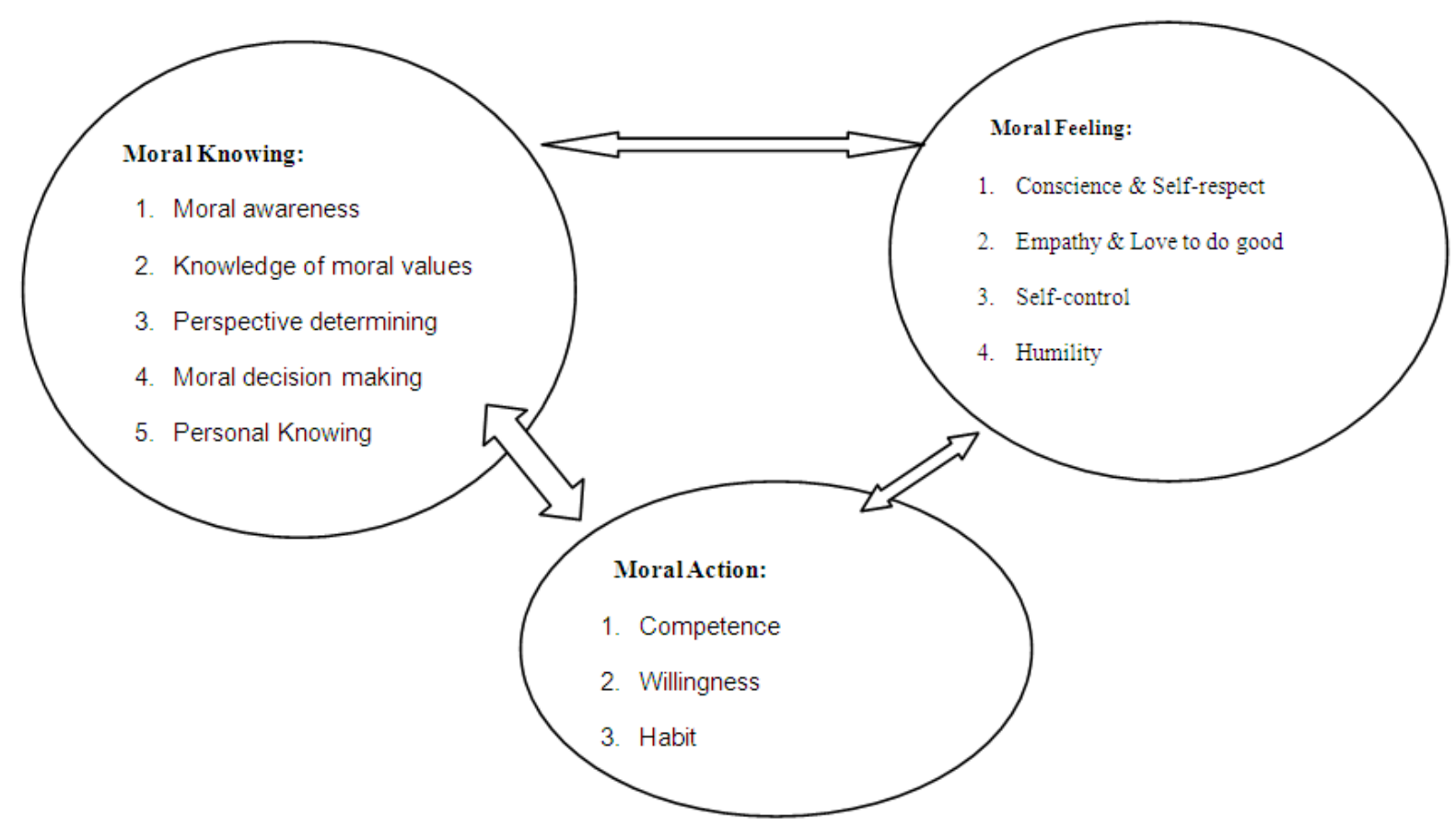

Figure 1. The components of good character (Source: Lickona, translated by Wamaungo (2012))

Character does not form by itself. That is, although human beings have innate potential to develop good character, this potential will not develop properly if it is not nurtured through education. Both formal and informal education is involved in the formation of a character. Furthermore, Lickona recommends three strategies as a comprehensive approach in internalizing moral values, namely: (1) classroom strategy, (2) broader child-rearing strategy outside the classroom, and (3) broader child-rearing strategy outside the school. This study used a classroom strategy. Teachers were expected to be able to instill values inside their classroom through the lessons they teach. Good character, which is the result of this kind of teaching, resembles a harvest for farmers. Accordingly, the paradigm is as Covey (1997) wrote, to "sow ideas and harvest deeds; sow deeds and harvest habits; sow habits and harvest fate." People are supposed to do something to achieve their aim.

A curriculum is required in administering education because it is the heart of education. Suparman (2005) summarizes a number of curriculum definitions proposed by professional educators in line with their basic philosophies as follows: 
- Curriculum is what is taught in an educational institution.

- Curriculum is a set of courses.

- Curriculum is everything that occurs at school, including extracurricular activities, counseling, and interpersonal relations.

- Curriculum is a set of experiences of students in an educational institution.

- Curriculum is what is taught inside and outside the school as directed by the educational institution.

The definitions above regarding the position of character in a curriculum have explicitly revealed where to place character matters in a curriculum. Nevertheless, it may generally be summarized that what is being taught is based on a set of experiences, namely everything that occurs at school. All these experiences suggest that the demand of the curriculum covers cognitive, affective, and psychomotor taxonomies. The inclusion of the affective taxonomy is essential according to the 2013 curriculum (Kementerian Pendidikan dan Kebudayaan, 2012) as indicated in Figure 2.
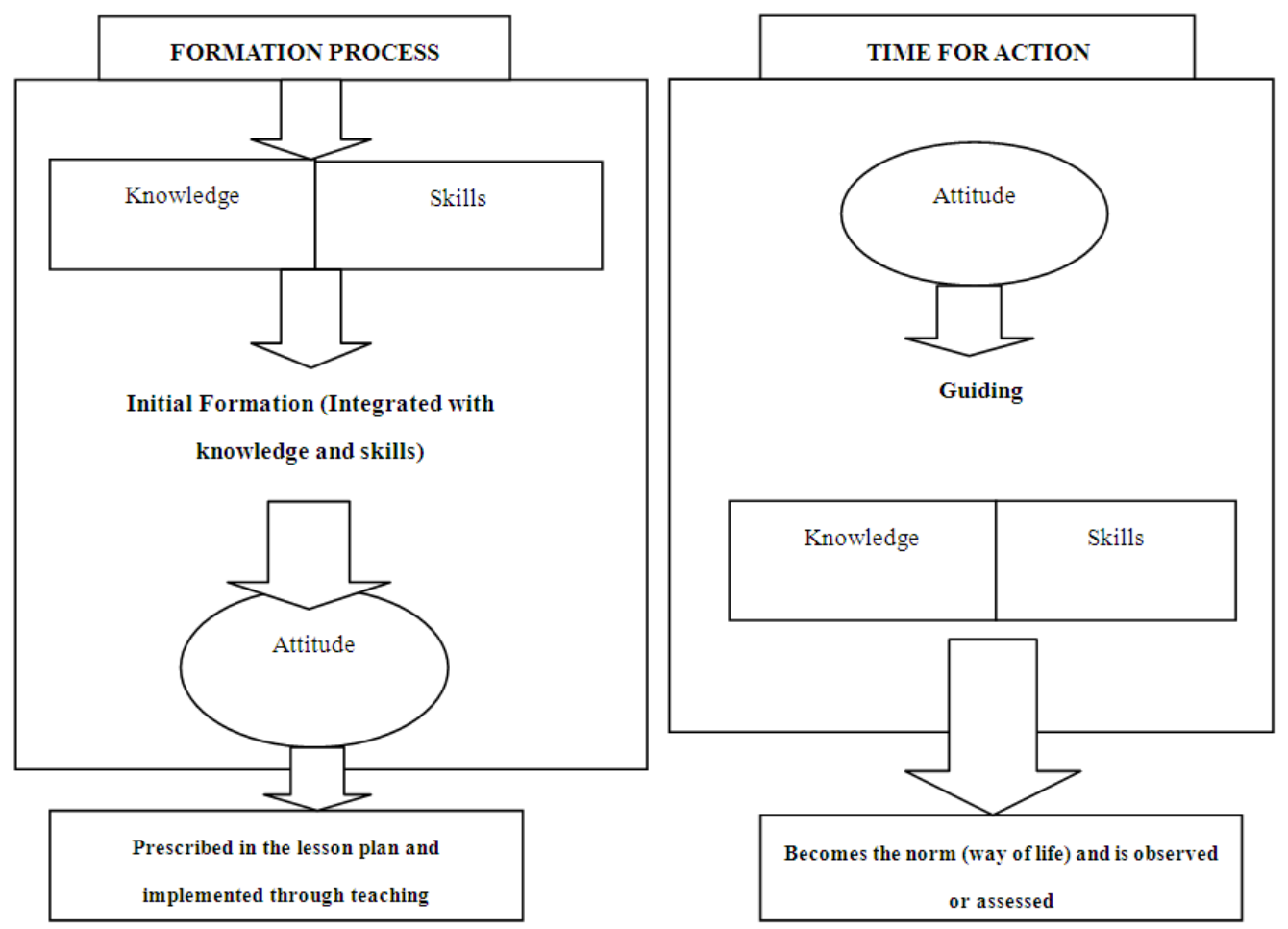

Figure 2. The essence of the 2013 curriculum (Source: Draft document of KTSP (School-based Curriculum of 2013))

As an instrument to achieve educational objectives, the curriculum has core and supplementary components that are closely related to one another. These components interact within a system to achieve their educational objectives. The 2013 curriculum is a continuation of the previous curricula "Competency-based Curriculum," which was initiated in 2004, and the School-based Curriculum in 2006. This curriculum covers competencies which include attitude, knowledge, and skills. The development of the 2013 curriculum is part of the strategy of promoting the targets of education. This curriculum has a more thorough approach, which is based on students' creativity. This new curriculum is believed to have fulfilled the three main components of education, namely knowledge, skills, and attitude, which will help the formation of the students' character.

The 2013 curriculum particularly aims to create a balance among attitude, skills, and knowledge. This aim is congruent with article 35 in the Constitution No. 20 of 2003, which says that the competence of the students must incorporate attitude, knowledge, and skills as stipulated in the national standard.

Based on these three components, a good character should be supported by knowledge about virtue, the will to do good, and a concrete action of doing good. In the 2013 curriculum, students are taught to have a whole 
character that can integrate their values into knowledge to overcome life's various problems.

The 2013 curriculum is a concept of education and culture that aims to develop good character on the part of students. From the perspective of knowledge and skills, students are encouraged to nurture creativity, innovation, and positive thinking in the development of a stronger and tougher generation of Indonesians in the future. This curriculum emphasizes the development of character in addition to skills and cognitive abilities.

Education is not only intended for the transfer of knowledge, but also for nurturing and developing good character so that the students will not only master knowledge, but also have a strong sense of character. A good character is so important that former United States President Theodore Roosevelt once said, "To educate a person in mind and not in morals is to educate a menace to society" (Megawangi, 2004). This statement signals the importance of an education orientated to moral values. Consequently, character or values education is not only the obligation of teachers of religion or civics education, and guidance and counseling teachers, but also of all teachers through an integration of values into their lessons (Figure 3).

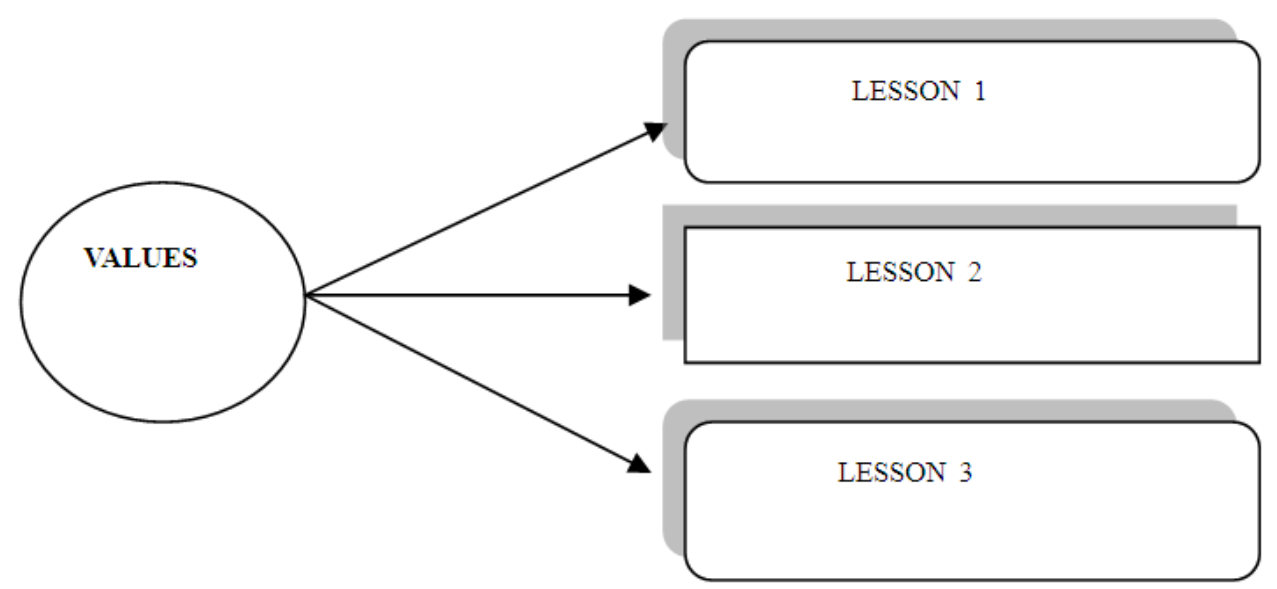

Figure 3. The integration of values into lessons (Source: Kementerian Pendidikan Nasional, Badan Penelitian dan Pengembangan Kurikulum (2010))

Eighteen values have been identified by the Ministry of Education as needing to be integrated into lessons. The teachers chose values that fit in with their lesson plans in accordance with the basic and core competencies that they taught. The values that were integrated were the cultural and national character values as described in Table 1.

Table 1. Description of cultural and national character values

\begin{tabular}{|c|c|c|}
\hline \multicolumn{2}{|c|}{ Values } & \multirow{2}{*}{$\begin{array}{l}\text { Description } \\
\text { An obedient attitude and behavior in applying religious teachings, tolerant } \\
\text { towards the practices of other religions and beliefs, and in harmony with } \\
\text { people having different religions. }\end{array}$} \\
\hline 1 & Religious & \\
\hline 2 & Honest & $\begin{array}{l}\text { Attitudes based on one's effort to make oneself a person who is } \\
\text { trustworthy in speech, action, and work. }\end{array}$ \\
\hline 3 & Tolerance & $\begin{array}{l}\text { Attitudes and actions that respect religions, ethnicity, opinions, attitudes, } \\
\text { and actions those are different from one's own. }\end{array}$ \\
\hline 4 & Disciplined & Orderly and conforms actions to all the rules and regulations. \\
\hline 5 & Hardworking & $\begin{array}{l}\text { A tenacious behavior in overcoming difficulties and in completing } \\
\text { learning tasks. }\end{array}$ \\
\hline 6 & Creative & $\begin{array}{l}\text { Thinking before doing something to discover new ways or results from } \\
\text { what one has at one's disposal. }\end{array}$ \\
\hline
\end{tabular}


7 Independent

8 Democratic

9 Curious

10 Nationalistic

11 Patriotic

12

Appreciative achievements

13 Friendly, communicative

14 Peace loving

15 Fond of reading

16

Environmentally aware

17 Socially concerned

18 Responsible
Attitudes and behaviors that do not depend on other people in completing assignments.

A way of thinking, behaving, and acting which views one's rights and obligations as equal to those of others.

Attitudes and action that generally seeks to discover more about what one learns, observes, and listens.

A way of thinking, acting, and viewing that places national interests higher than personal or communal interests.

A way of thinking and doing that reflects faithfulness, care, and respect for the national language, along with the land, social, economic, and political aspects of the community.

of Attitudes and actions of encouraging oneself to produce something useful of the society while also acknowledging what others do.

Actions that demonstrate an eagerness to converse, interact, and cooperate with other people.

Attitudes, speech, and actions that cause other people to feel happy and secure due to one's presence.

The habit to provide time for reading various materials to learn insights and other virtues for oneself.

Attitudes and actions that generally seeks to prevent damage in the natural environment and to make efforts to repair environmental damage that has occurred.

Attitudes and actions that tend to assist other people who need help.

Attitudes and behaviors that assume the obligation to finish assignments and tasks and to take care of oneself, the society, the environment, the country, and God.

Source: Kementerian Pendidikan Nasional, Badan Penelitian dan Pengembangan Kurikulum (2010).

The government has to promote the quality of graduates from elementary schools, junior high schools, senior high schools, and universities. To achieve this target, the Ministry of Education has established a standard called the Graduate Competency Standards that cover attitude, skills, and knowledge for graduates (Table 2).

Table 2. Graduate Competency Standards

\begin{tabular}{lll}
\hline & - & Having behavior that reflects a good attitude. \\
Attitude & - & $\begin{array}{l}\text { Pious, having good deeds, self-confident, and responsible for the social and natural } \\
\text { environment. }\end{array}$ \\
& - & Positioning oneself as a reflection of the nation in the international world. \\
\hline \multirow{2}{*}{ Skills } & - & $\begin{array}{l}\text { Having thinking abilities and effective and creative actions in both abstract and concrete } \\
\text { contexts. }\end{array}$ \\
& - & Having developed skills taught at school based on students' talents, interests, and abilities. \\
Knowledge & - & $\begin{array}{l}\text { Having procedural and metacognitive knowledge in science, technology, arts, culture, and } \\
\text { humanities with a national perspective. }\end{array}$ \\
& Having knowledge about the causes of phenomena and events along with alternative \\
& solutions, hindrances, and final solutions.
\end{tabular}

Source: Draft dokumen KTSP dan Kurikulum (2013).

The above-mentioned values in the 2013 curriculum are categorized into core competence 1 (CC-1) about 
spiritual or religious attitudes and core competence 2 (CC-2) about social attitudes. Learning materials are related to knowledge and skills, which are further categorized into core competence 3 (CC-3) about knowledge and core competence 4 (CC-4) about skills.

In the subject of economics in high school, there are essentially two types of competence that have to be taught to students, Core Competencies (CC) and basic competence (BC), in line with the draft document of the school-based curriculum (Draft dokumen KTSP dan Kurikulum, 2013). Table 3 is an example of the CC and BC details in a syllabus for 10th-grade high school economics.

Table 3. CC/BC of economics for 10th-grade high school students

$\mathrm{CC} \quad \mathrm{BC}$

To be grateful for all the resources endowed by God

To fully comprehend and apply religious teachings. the Almighty to fulfill people's needs.

To apply religious teachings in managing banking finance and the finance of other institutions.

To develop good behaviors (honesty, discipline, responsibility, care, politeness, environmental kindness, helping one another, cooperation, peace loving, responsiveness, and proactivity) and to show good attitudes as solutions for various national problems in interacting with the social and natural environment and to place oneself as a reflection of the nation in global relations.

To have caring, disciplined, and responsible attitudes in overcoming the problem of resource scarcity.

To have caring, creative, cooperative and independent attitudes in overcoming economic problems in the social environment.

To analyze scarcity (the relations between resources and people's needs) and strategies to overcome resource scarcity.

To analyze the basic issues of economics (what, how, and for whom are economic resources) and alternative solutions through various economic systems.

To understand and apply factual, conceptual and procedural knowledge in science, technology, arts, culture, and humanities with human, national, and civil perspectives as well as implementing procedural knowledge in specific areas based on personal interests and talents to solve problems.

To understand the behaviors of consumers and producers, and their roles in economic activities.

To understand the market and forms of markets (monopoly, oligopoly, free enterprise competition, and monopolistic competition) and their roles in our economy.

To analyze both micro- and macroeconomic problems and policies.

To understand the concepts, methods, and benefits of computing national income.

To understand financial institutions such as banking and other financial institutions (their concepts, functions, roles, and products).

To understand the basic concepts of stock exchange and its role in economics 
To present the concepts of demand, supply, and balances in the forms of schedules/tables, functions, and curves.

To manage, rationalize and present issues in both concrete and abstract contexts related to things learned at school in an independent manner and to be able to use methods according to scientific rules.
To describe functions, consumption, saving, investment, and balance income in graphic forms in a closed economy or two sectors' economy.

To compute price indices and inflation (concepts, factors, and inflation effect on Indonesian economy).

To present the concept of demand and supply of money in the form of functions and graphics.

Source: Draft dokumen KTSP dan Kurikulum (2013).

A learning model is necessary to integrate character education into all subjects; it is intended to be a reference for undertaking the learning process. Joyce and Weil (1980) says that "a model teaching is a plan or pattern that can be used to shape curriculums (long-term courses of studies), to design instructional materials, and to guide instruction in the classroom and other settings." Winataputra (2005) summarizes that a leaning model is a conceptual frame that describes systematic procedures for organizing learning experiences aimed at achieving specific learning objectives and functions as a guideline for learning designers and teachers to plan and implement their teaching activities. Accordingly, this study aims to design a model that might be able to help teachers to organize their teaching-learning activities to integrate values into their learning materials.

The learning model was designed through lesson plans, which are short-term teaching-learning plans that need to be developed to infuse moral values into students. With a lesson plan designed in this way, teachers will remember to teach these values to their students. Therefore, this model is specifically designed to integrate the teaching of values into other subjects, particularly economics. In this learning model, teachers have to improvise (Rusman, 2010) by relating the lesson plan to the values appropriate to be taught. For instance, when a teacher is teaching natural resources in Indonesia, the teacher should remind the students that these resources are endowed by God the Creator. Indonesian people need to be grateful for this kind of endowment. By connecting material values to moral values, the teacher is actually improvising their teaching of values indirectly. Another example is when the teacher explains the fact that these natural resources are limited, the teacher might say that in life we should not be greedy with resources, and that it is essential that we share our resources with other people. This sort of improvisation facilitates the integration of moral teaching into the subject being taught. In improvising, teachers may use a religious approach or they may also use national cultural values such as heroism. Teachers may draw upon stories that contain good behaviors or attitudes.

\section{Findings and Discussion}

This study used a qualitative method. Data were obtained by observing and interviewing economics teachers in public schools in the city of Banjarmasin, Indonesia. Five schools were selected purposively from 13 public high schools in Banjarmasin. These five schools were considered to sufficiently represent all the public schools because it was believed that the amount of data obtained had reached the level of saturation. Thus, it was thought that there would be no more new patterns revealed (Satori \& Komariah, 2009). This study has generated a model and this model was validated against teachers who teach other subjects. In addition, a triangulation has been undertaken in related institutions. This model reflects what has been done by teachers combined with a systematic formulation of how to integrate values into the teaching of economics.

In general, economics teachers in Banjarmasin public schools undertook teaching-learning processes by integrating 18 values into economics. They were able to mention the values that were incorporated into each BC. Judging from their syllabuses, it would appear that CC-1 and CC-2 are not directly related to the BC. Ideally, CC-1 and CC-2 have to be related. Similarly, CC-3 and CC-4 have to be related. Teachers' comprehension of what is written in their syllabuses makes CC-1 and CC-2 seem unrelated or separate from CC-3 and CC-4, and from all the other BCs.

As shown by Table 3, it seems that CC-1 and CC-2 have their own BC and the results of their teaching-learning processes also appear to be separate from the success of individual competencies. There does not appear to be integration (Figure 4). 


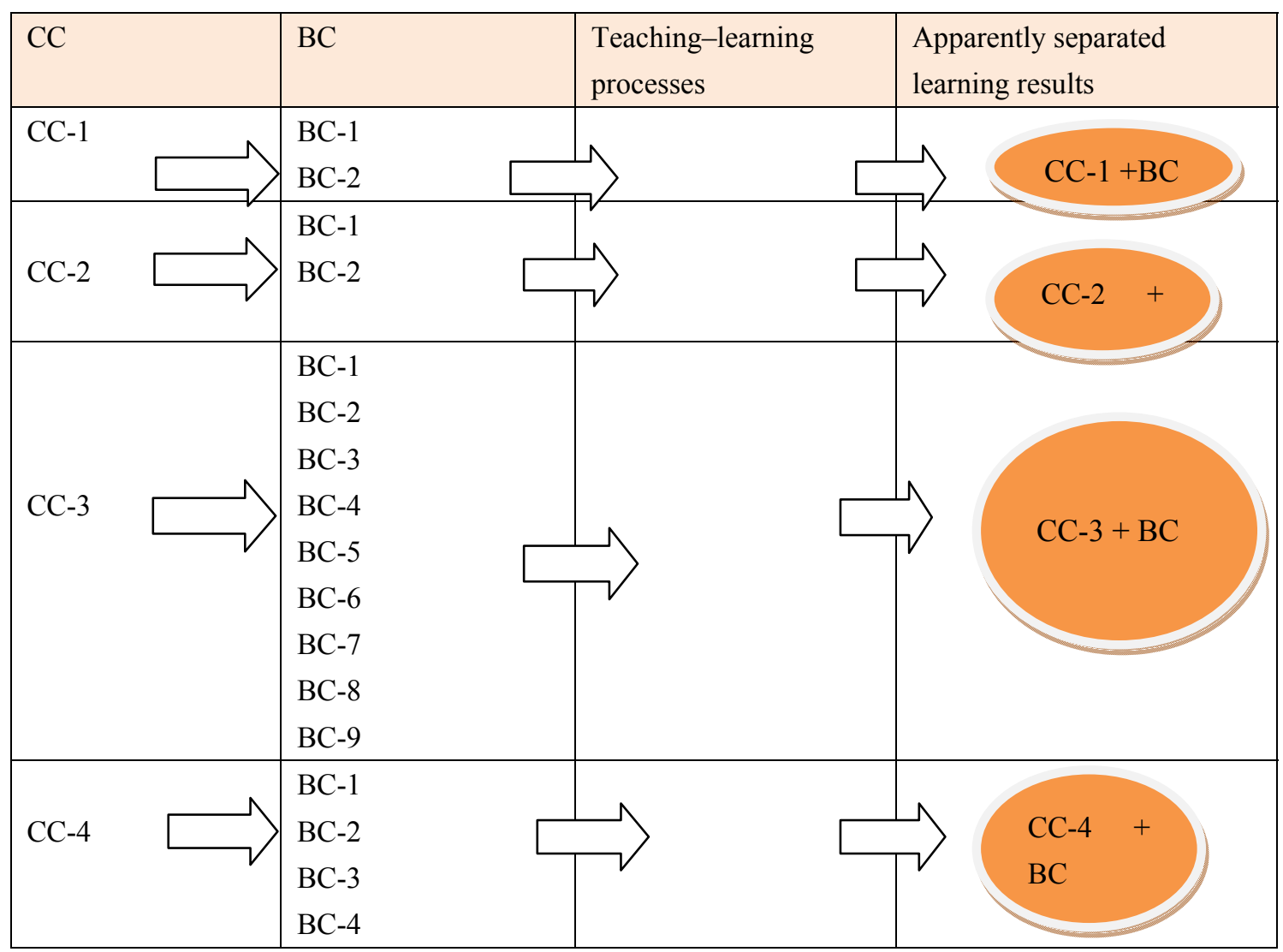

Figure 4. A learning model of character/values that appear to be integrated

Because of doubts on the part of the teachers about an apparent separation of CC- 1 and CC-2 from CC-3 and CC-4, this study seeks to clarify their relationships with the following model (Figure 5).

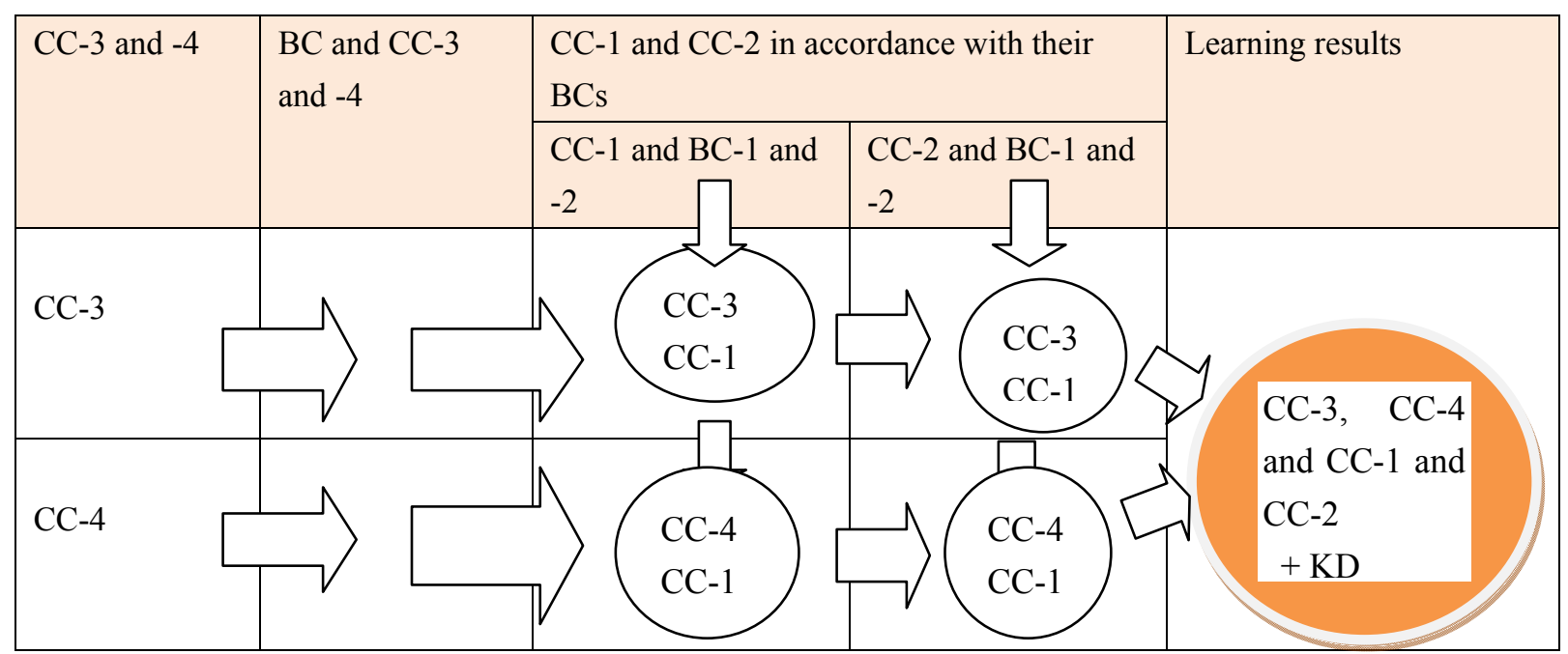

Figure 5. An integrated model of character/values in the subject of economics

In the model in Figure 5, teachers have to determine the CC-3 and CC-4 that they are going to convey from their syllabus. Later on, they have to think about how to combine those values with CC-1 and CC-2 so that they are neatly integrated into their lessons.

All those values were included and written in their lesson plans as a whole, which indicates that those economics teachers had done their jobs well. The teachers appeared to be able to choose the values they wrote in their 
lesson plans. However, it appeared that they were still in doubt about integrating such values into their lessons. They concentrated on their materials too much so that they forgot about these values.

As for the notes for guiding the integration of values, this study came up with an example by using only one of the basic competencies, namely BC-3.2 for the 10th grade classes. The BC-3.2 mentions that the BC is to analyze scarcity, which is the relationship between resources and people's needs and the relationship between people's needs and their strategies to overcome resource scarcity.

\section{Conclusions}

The 2013 curriculum stipulates that teaching-learning processes necessitate teachers to integrate values into their subjects. These values should not only be taught by teachers of religions or civics education, and guidance and counseling teachers, but also by all teachers teaching different subjects. The teaching of values will be more effective if it is conveyed through other subjects considering that teachers of other subjects are knowledgeable about their fields so that they know exactly where these values may be found in their subjects. Economics teachers know that there are 18 values recommended to be taught to the students in terms of CC-1 and -2 . Later on, $\mathrm{CC}-1$ and -2 will be combined with CC-3 and -4 . The integration of the four CCs is expected to make learning processes meet the Graduate Competency Standards.

To boost the effectiveness of the integration of values into the teaching of economics, teachers should have extra knowledge about character education. It takes improvisation on the part of the teacher to be able to convey character education through their own subjects so that the value-based messages get through the students. To ensure that this improvisation does not waste much time, it is advised that the teachers' improvisation should be documented as attachments in lesson plans or at least it should be collected by the teacher to contribute to value-based education.

\section{References}

Covey, S. (1997). The 7 Habits of Highly Effective People (7 Kebiasaan Manusia yang Sangat Efectif). Alih bahasa Budiyanto, Binarupa Aksara Jakarta.

Departemen Pendidikan Nasional. (2003). Undang-undang Sistem Pendidikan Nasional. Nomor 20 Tahun 2003, Jakarta.

Depdiknas. (2007). Model Silabus Kurikulum Tingkat Satuan Pendidikan, Jakarta.

Draft dokumen KTSP dan Kurikulum. (2013). Retreived November 23, 2013, from http://fokus.news.viva.co.id/news/read/371744-kurikulum pendidikan-2013

El-mubarok, Z. (2008). Membumikan Pendidikan Nilai, Mengumpulkan yang Terserak, Menyambung yang Terputus dan Menyatukan yang Tercerai, Alfabeta, Bandung.

Fadillah. (2010). Pengembangan Model Pembinaan Nilai Kejujuran Melalui Pendidikan Matimatika Sebagai Upaya Meningkatkan Kecerdasan Moral Peserta Didik. Disertas yang telah diserahkan kepada Sekolah Pascasarjana, Universitas Pendidikan Indonesia, sebagai Salah Satu Persyaratan Kelulusan.

Joyce, B. R., \& Weil, M. (1980). Models of Teaching. Prentice-Hall, Inc., Englewood Cliffs, New Jersey.

Kementerian Pendidikan dan Kebudayaan. (2012). Dokumen Kurikulum 2013. Retreived May 25, 2015, from http://tania.fkip.uns.ac.id/wp-content/uploads/dokumen-kurikulum-2013.pdf

Kementerian Pendidikan Nasional, Badan Penilitian dan Pengembangan Kurikulum. (2010). Bahan Pelatihan Penguatan Metodologi Pembelajaran Berdasarkan Nilai-Nilai Budaya untuk Membentuk Daya Saing dan Karakter Bangsa "Pengembangan Pendidikan Kewirausahaan".

Lickona, T. (1992). Educating for Character, Mendidik Untuk Membentuk Karakter, a translation by Wamaungo $J$, Abdu (2012). PT. Bumi Aksara, Jakarta.

Megawangi, R. (2004). Pendidikan Karakter, Solusi yang tepat untuk membangun bangsa. BP MIGAS, Jakarta.

Poerwanti, E. (2011). Klusterisasi Nilai-nilai Moral Universal Sebagai Landasan Pengembangan Karakter. Diges Pendidik Universiti Sains Malaysia \&UPI Bandung, Jilid 11, Bil.1/2011.

Rusman. (2010). Model-.Model Pembelajaran Mengembangkan Profesional Guru. Rajawali Press, Jakarta.

Satori, K. (2009). Metodologi Penelitian Kualitatif. Alfabeta Bandung

Suparman, D. (2005). Konsep dasar Pengembangan Kurikulum. PAU-PPAI-UT Jakarta.

Winataputra, U. (2005). Model-Model Pembelajaran Inovatif. PAU-PPAI-UTJakarta. 


\section{Copyrights}

Copyright for this article is retained by the author(s), with first publication rights granted to the journal.

This is an open-access article distributed under the terms and conditions of the Creative Commons Attribution license (http://creativecommons.org/licenses/by/3.0/). 